\title{
Antigen cross-presentation of immune complexes
}

\section{Barbara Platzer, Madeleine Stout and Edda Fiebiger *}

Department of Pediatrics, Division of Gastroenterology and Nutrition, Boston Children's Hospital, Harvard Medical School, Boston, MA, USA

\section{Edited by:}

Marianne Boes, University Medical Centre Utrecht, Netherlands

\section{Reviewed by:}

Andrew Mark Lew, Walter and Eliza Hall Institute of Medical Research,

Australia

Xinjian Chen, University of Utah, USA

*Correspondence:

Edda Fiebiger, Department of

Pediatrics, Division of

Gastroenterology and Nutrition,

Boston Children's Hospital, Harvard

Medical School, 300 Longwood

Avenue, Enders 630, Boston, MA

02115, USA

e-mail: edda.fiebiger@childrens.

harvard.edu
The ability of dendritic cells (DCs) to cross-present tumor antigens has long been a focus of interest to physicians, as well as basic scientists, that aim to establish efficient cell-based cancer immune therapy. A prerequisite for exploiting this pathway for therapeutic purposes is a better understanding of the mechanisms that underlie the induction of tumor-specific cytotoxic T-lymphocyte (CTL) responses when initiated by DCs via cross-presentation. The ability of humans DC to perform cross-presentation is of utmost interest, as this cell type is a main target for cell-based immunotherapy in humans. The outcome of a crosspresentation event is guided by the nature of the antigen, the form of antigen uptake, and the subpopulation of DCs that performs presentation. Generally, CD $8 \alpha^{+}$DCs are considered to be the most potent cross-presenting DCs. This paradigm, however, only applies to soluble antigens. During adaptive immune responses, immune complexes form when antibodies interact with their specific epitopes on soluble antigens. Immunoglobulin G (lgG) immune complexes target Fc-gamma receptors on DCs to shuttle exogenous antigens efficiently into the cross-presentation pathway. This receptor-mediated cross-presentation pathway is a well-described route for the induction of strong CD8 ${ }^{+} \mathrm{T}$ cell responses. IgGmediated cross-presentation is intriguing because it permits the $\mathrm{CD}^{-} \mathrm{DCs}$, which are commonly considered to be weak cross-presenters, to efficiently cross-present. Engaging multiple DC subtypes for cross-presentation might be a superior strategy to boost CTL responses in vivo. We here summarize our current understanding of how DCs use IgG-complexed antigens for the efficient induction of CTL responses. Because of its importance for human cell therapy, we also review the recent advances in the characterization of cross-presentation properties of human DC subsets.

Keywords: anti-tumor immune responses, DC subset functions, cell type-specific cross-presentation, IgGcomplexed antigens, Fc receptor-mediated antigen uptake, $\mathrm{CD8}^{+} \mathrm{T}$ cell priming

\section{INTRODUCTION}

The mechanism of cross-presentation allows exogenous antigens to access the processing and presentation machinery of a cell so that exogenous antigenic peptides are displayed on MHC class I molecules for $\mathrm{T}$ cell recognition, which consequently leads to the priming of $\mathrm{CD} 8^{+} \mathrm{T}$ cell responses. As such, the cross-presentation pathway is essential for inducing cytotoxic T-lymphocyte (CTL) responses against viruses as well as intracellular bacteria, which do not infect the APC (1-4). Additionally, cross-presentation is thought to be crucial in mounting immune responses against tumor antigens. Indeed, cross-priming of tumor reactive cytotoxic $\mathrm{CD}^{+} \mathrm{T}$ cells through cell-based tumor vaccines is a major goal in cancer immunotherapy $(5,6)$. Induction, the so called priming, of tumor-specific $\mathrm{CD} 8^{+} \mathrm{T}$ cells is an appealing therapeutic strategy because the generated CTLs not only mediate antigenspecific killing of the targeted tumor via cell-cell contacts, but also provide the host with long-lasting memory responses that may prevent cancer recurrence.

Dendritic cells (DCs) have been proven to be superior in routing exogenous protein antigen toward cross-presentation; however, they comprise a heterogeneous cell population, and significant differences in the cross-presentation capacity of different DC subsets have been reported (4). Importantly, cross-presentation of antigen does not result solely in the priming of CTLs but can also lead to the induction of cross-tolerance (7). The latter immunological outcome should by all means be avoided during cancer therapy. Thus, to take full advantage of the therapeutic potential of antigen cross-presentation by DCs, significant effort was made to delineate precisely how cross-presentation is initiated and regulated. By now, many mechanistic details of antigen cross-presentation have been discovered whereas others still remain enigmatic. In contrast to MHC class II-restricted antigen presentation, the default pathway for the display of exogenous antigens for immune recognition and the induction of $\mathrm{CD} 4^{+} \mathrm{T}$ cell responses, cross-presentation in vivo is thought to be controlled rather strictly by the type of DCs used as antigen-presenting cells. In this review, we summarize the current knowledge on how immune complexes facilitate antigen cross-presentation and expand the cross-presentation capacity of specific DC subsets. We also discuss the therapeutic potential of this cross-presentation pathway.

\section{IgG IMMUNE-COMPLEXED ANTIGENS ENTER THE} CROSS-PRESENTATION PATHWAY THROUGH FC RECEPTORS

Our immune system has to respond to a variety of different forms of antigens and thus has developed an array of mechanisms to 
deal with antigenic diversity. Antigens can be small soluble molecules, which are taken up by fluid phase mechanisms, or larger particles, such as bacteria, which are phagocytosed. To facilitate antigen uptake and processing, DCs also use an assortment of endocytic receptors (Figure 1). Several of these endocytic receptors belong to the C-type lectin family. For example, DEC-205, the mannose receptor, and Clec9a have been shown to efficiently shuttle antigen for cross-presentation. Several recent reviews give detailed insight into the functional differences of these endocytic receptors, and they are therefore only briefly mentioned here (810). Importantly, monoclonal antibodies against these endocytic receptors have been employed to target antigen to DCs for crosspresentation, and using this strategy, encouraging anti-tumor immunity was initiated in mice (11-13). Thus, strong emphasis is continuously put on targeting of cross-presenting DCs to elicit anti-tumor responses, as exhibited in several ongoing clinical trials (11, 14-16). A so far therapeutically less exploited but remarkably effective way for DCs to internalize antigen for cross-presentation is via Fc receptors (Figure 1). Antigens, especially under inflammatory conditions, can be found already bound to antigen-specific antibodies, and these antigen-antibody complexes (referred to as immune complexes or immune-complexed antigen) can be recognized by Fc receptors through the Fc region of the antibodies. Binding of the immune complexes typically triggers crosslinking of the $\mathrm{Fc}$ receptors, their internalization together with the antigen, and shuttling of the immune complexes toward antigen presentation compartments $(17,18)$.

Before the crucial role of Fc receptors in antigen crosspresentation was identified, their value in enhancing antibodydependent cellular cytotoxicity (ADCC) by inflammatory cells, including neutrophils and macrophages, was already recognized (19). Enhancement of T cell proliferation via antigen-specific antibodies that bind Fc receptors became evident in the mid-1980s (20-22). Studies using Fc $\gamma$ receptor knockout mice revealed the general requirement of $\mathrm{Fc} \gamma$ receptor engagement for the effectiveness of anti-tumor immune responses in vivo. The finding that anti-tumor antibodies require the induction of CTL responses to be effective suggested early on that $\mathrm{Fc} \gamma$ receptors contribute to anti-tumor immunity in addition to mediating ADCC (23). Shortly after, it was compellingly demonstrated that endocytosis of immune complexes via Fc $\gamma$ receptor allows $\mathrm{MHC}$ class I-restricted antigen presentation and the priming of CTLs $(24,25)$. The finding that DCs use immunoglobulin G (IgG)-immune complexes to efficiently prime specific $\mathrm{CD} 8^{+} \mathrm{CTL}$ responses was shortly thereafter confirmed in vivo (26). Furthermore, it was shown that only antigen targeting to $\mathrm{Fc} \gamma \mathrm{R}$ on DCs, but not antigen targeting to surface immunoglobulins on B cells, induces efficient crosspresentation, despite the fact that both targeting strategies allow these cell types to present antigen via MHC class II with equal efficiency (27).

The therapeutic potential of Fc receptor-mediated antigen uptake for anti-tumor immunotherapy became evident early on. Studies with human cells demonstrated that coating human myeloma cells with monoclonal antibodies promotes crosspresentation of myeloma-associated antigens by human DCs. The enhanced cross-presentation of tumor antigen was preventable by pretreatment of the DCs using Fc $\gamma$ receptor blocking antibodies (28). Notably, this study did not observe that Fc $\gamma$ receptormediated antigen uptake induces significant phenotypic maturation of human DCs, as it has been described for murine DCs $(24,26,27)$. The possible absence of maturation induction in human DCs through immune complexes is important to keep in mind with regard to a clinical applicability of Fc receptor targeting. DC maturation in the context of antigen uptake is considered to be a crucial attribute that must be achieved to induce efficient CTL responses by cross-presentation receptors because otherwise cross-tolerance may be induced (7). Overall, although there is substantial evidence suggesting that cross-presentation of immune-complexed antigen via Fc $\gamma$ receptors is a promising tool to develop DC-based vaccination strategies, there are several factors, which we will discuss below, that have so far hampered the applicability.

\section{Receptor-mediated uptake}

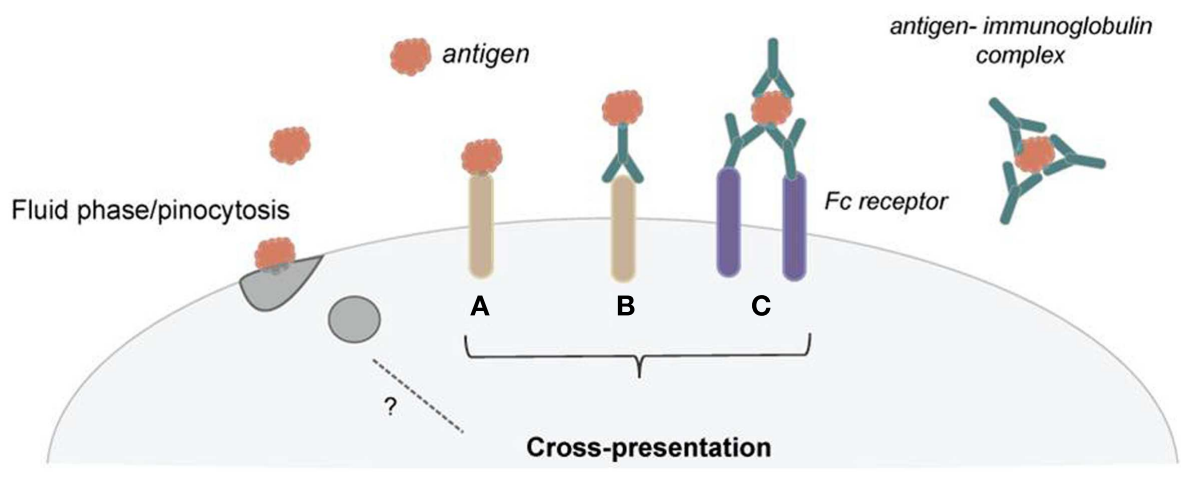

FIGURE 1 | Dendritic cells use several mechanisms of antigen uptake for cross-presentation. (A) Several receptors have been shown to efficiently shuttle exogenous antigen into the cross-presentation pathway. (B) These receptors are now employed to target DCs in vivo for cancer immunotherapy using receptor-specific antibodies coupled with antigen. (C) Immunoglobulins can bind to antigen and form immune complexes. These immune complexes can then be taken up via Fc receptors and deliver antigen for cross-presentation. Pinocytosis seems not to be an effective mechanism for routing antigen toward cross-presentation. 


\section{CROSS-PRESENTATION OF IMMUNE COMPLEXES AND THE} DIVERSITY OF FC RECEPTORS

A major difficulty for studying and determining the therapeutic applicability of cross-presentation of immune complexes is the complexity of the Fc $\gamma$ receptor family [Table 1; Ref. (29)]. Several types of $\mathrm{Fc}$ receptors have been found in addition to speciesdependent differences. In mice, four different classes of Fc $\gamma$ receptors comprising Fc $\gamma$ RI, Fc $\gamma$ RIIB, Fc $\gamma$ RIII, and Fc $\gamma$ RIV have been described. The activating Fc receptors Fc $\gamma$ RI, Fc $\gamma$ RIII, and Fc $\gamma$ RIV consist of an immunoglobulin binding $\alpha$-chain and a signal transducing $\gamma$-chain, which carries an immunoreceptor tyrosinebased activation motif (ITAM). In contrast, Fc $\gamma$ RIIB is a single chain inhibitory receptor with an immunoreceptor tyrosine-based inhibitory motif (ITIM). The human Fc $\gamma$ R system seems to be far more complex as exemplified by the presence of gene families for Fc $\gamma$ RI and Fc $\gamma$ RII, as well as the presence of several allelic forms for Fc $\gamma$ RIIIA, Fc $\gamma$ RIIIB, and Fc $\gamma$ RIIB. Mouse Fc $\gamma$ RIV is most closely related to human Fc $\gamma$ RIIIA whereas mouse Fc $\gamma$ RIII is most similar to human Fc $\gamma$ RIIA. Fc $\gamma$ RIIIB is unique for the human system, but both species have the inhibitory function of Fc $\gamma$ RIIB in common.

Dendritic cells simultaneously express activating and inhibitory Fc receptors [reviewed in Ref. (18)]. The conserved expression of an inhibitory Fc receptor along with activating Fc receptors among species suggests that $\mathrm{Fc}$ receptor-mediated crosspresentation is tightly regulated in vivo. The requirement of strictly controlling Fc receptor-mediated cross-presentation was demonstrated by studies that show that antibody-mediated crosspresentation of self-antigens contributes to autoimmune disease $(34,35)$. The authors looked at the development of autoimmune diabetes in RIP-OVA mice. In this model, the transfer of OVA-specific naïve $\mathrm{CD}^{+} \mathrm{T}$ cells induces peripheral tolerance. Importantly, the co-administration of anti-OVA IgG leads to $\mathrm{CD}^{+} \mathrm{T}$ cell-driven diabetes through the activating Fc $\gamma$ receptors on DCs. The disease pathogenesis in this model was further augmented in Fc $\gamma$ RIIB knockout mice, suggesting a tolerogenic function of FcrRIIB in vivo. In line with a tolerogenic function of this receptor, it was shown that DCs from Fc $\gamma$ RIIB knockout mice generate overall stronger immune responses and that blocking immune complex binding to Fc $\gamma$ RIIB promotes DC maturation, which is considered one of the most important factors for efficient priming of CTL responses (36-39). This suggests that expression of inhibitory Fc $\gamma$ RIIB, which restricts DC maturation under non-inflammatory conditions and thus probably prevents autoimmunity, may hamper immunotherapeutic approaches against tumors and microbial infections $(29,40)$. Hence, it is important to be aware of the expression patterns and ratios of activating versus inhibitory $F_{c}$ receptors on murine and human DCs when studying the effects of immune complexes.

Additionally, IgG subclass composition of immune complexes has been shown to influence binding affinity resulting in different binding properties to individual Fc receptors (41). For example, immune complexes composed of human IgG1 bind with relatively high affinities to all $\mathrm{Fc}$ receptors, whereas IgG2 immune complexes seem to bind primarily to human Fc $\gamma$ RIIA and Fc $\gamma$ RIIIA (42). Furthermore, disparities in the binding affinities of immunoglobulin isotypes for specific $\mathrm{Fc} \gamma$ receptors exist between mice and humans. Thus, predictions of immune complex functions drawn from wild-type mouse models might be inadequate. A prominent example of the failure of previous studies in accurately recapitulating the specificity and diversity of $\mathrm{Fc} \gamma$ receptor interactions is the outcome of a clinical trial using a CD28-specific superagonistic antibody; this led to severe side effects including severe pain and extreme swelling, as well as one individual suffering from heart, liver, and kidney failure (43). To address this problem, an Fc $\gamma \mathrm{R}$ humanized mouse strain was recently generated through transgenic expression of the entire human Fc $\gamma \mathrm{R}$ family under the control of their human regulatory elements on a genetic background lacking all mouse Fc $\gamma$ Rs (44). The animals demonstrate normal lymphoid tissue development and generate normal immune responses. Thus, this mouse strain offers a greatly improved model to study immune complex-mediated cross-presentation, although it addresses only the species-specific differences regarding $\mathrm{F} c \gamma$ receptors. Humans and mice also display differences in the expression patterns of $\mathrm{Fc}$ receptors for IgE and IgA, which might contribute to cross-presentation of immune-complexed antigen in vivo (45-48).

Increasing evidence suggests that allelic isoforms and polymorphisms of Fc receptors are shaping immune responses in humans. Fc $\gamma$ RIIA (CD32A), the major phagocytic Fc $\gamma$ R in humans, exhibits a polymorphism in the ligand-binding domain (49). Individuals homozygous for the $\mathrm{R}$ allelic form of CD32A (CD32AR allele) have been described as more susceptible to bacterial infections and autoimmune diseases compared to individuals homozygous for the $\mathrm{H}$ allelic form of CD32A (CD32AH) and CD32AR/H heterozygous individuals $(50,51)$. A binding study using two-dimensional affinity measurements also demonstrated

Table 1 | Overview of human and murine Fc $\gamma$ receptors.

\begin{tabular}{|c|c|c|c|c|c|}
\hline Human/mouse & IgG receptor & CD & Function & Affinity & Structure \\
\hline \multirow[t]{3}{*}{ Human (30-33) } & Fc $\gamma R I I A$ & CD32A & Activation & Low to medium & $\alpha$-Chain with ITAM \\
\hline & Fc $\gamma$ RIIC & $\mathrm{CD} 32 \mathrm{C}$ & Activation & Low to medium & $\alpha$-Chain with ITAM \\
\hline & Fc $\gamma R I I I B$ & CD16B & Activation & Low to medium & GPI-linked $\alpha$-chain \\
\hline Human and mouse (30-33) & $\mathrm{Fc} \gamma \mathrm{Rl}$ & CD64 & Activation & High & $\alpha$-Chain and $\gamma_{2}$-chains with ITAM \\
\hline \multirow[t]{2}{*}{ Mouse (30-33) } & Fc $\gamma R I I I$ & CD16 & Activation & Low to medium & $\alpha$-Chain and $\gamma_{2}$-chains with ITAM \\
\hline & Fc $\gamma$ RIV & & Activation & Low to medium & $\alpha$-Chain and $\gamma_{2}$-chains with ITAM \\
\hline
\end{tabular}


that compared to CD32AH, CD32AR has significantly lower affinity toward IgG2, as well as to IgG1 and IgG3, suggesting that the lower binding of CD32AR to IgGs might be responsible for the lack of immune complex clearance, which leads to increased susceptibility to bacterial infections and autoimmune diseases (52). Genetic variations in $\mathrm{Fc}$ receptors have also been linked to cancer susceptibility (53-55). However, less efficient immune complex binding might also be reflected in less efficient antigen uptake and presentation via this receptor, and thus consequences for immune complexes cross-presentation should be expected. Of note, glycosylations in the IgG-Fc region can also affect Fc receptor-binding properties as discussed in detail in a recent review (56). How antigen cross-presentation of immune complexes and $\mathrm{T}$ cell priming is altered by differences in IgG subclass composition, IgG-Fc glycosylation, and Fc receptor polymorphisms is currently unknown, but is important to address. In conclusion, the complexity of interactions of IgG with the Fc receptor system in addition to concerns about species specificity presents a major hurdle that needs to be overcome for successful therapeutic applications.

\section{CROSS-PRESENTATION OF IMIMUNE COMPLEXES AND THE DIVERSITY OF DC SUBPOPULATIONS}

Whether it would be beneficial to target a specific DC subset that displays a superior capacity to cross-present antigen for therapeutic approaches is currently a field of extensive investigation $(4,57)$. We will first focus on what we know so far about the cross-presentation capacity of DC subsets in general and then discuss our current understanding of cross-presentation of immune complexes in regard to DC subsets. DCs are a heterogeneous cell population, and substantial effort was made to characterize different subsets in mice and identify their human counterparts [reviewed in Ref. (58-60)]. In principal, murine and human DCs can be divided into two major subsets, classical/conventional DCs (cDCs) and plasmacytoid DCs (pDCs). In mice, cDCs comprise $\mathrm{CD} 8 \alpha^{+}$and $\mathrm{CD} 8 \alpha^{-}$lineages, which have been found to differ in their ontogeny and display functional specializations. Since the expression of surface markers on human and murine DCs is not conserved, only recently has gene expression profiling allowed for the identification of human $\mathrm{CD} 141^{+}$DCs as functional equivalents of the mouse $\mathrm{CD} 8 \alpha^{+} \mathrm{DCs}$, while human $\mathrm{CD} 1 \mathrm{c}^{+} \mathrm{DCs}$ appear to be comparable to mouse CD8- DCs $(61,62)$.

In mice, the $\mathrm{CD} 8 \alpha^{+}$DC subset is considered to be more efficient at antigen cross-presentation than other DC subsets (63-66). The corresponding human subset, $\mathrm{CD} 141^{+} \mathrm{DCs}$, is also potent at inducing $\mathrm{CD}^{+} \mathrm{T}$ cell responses in vitro, although their superiority to other human DC subsets is uncertain (67-73). Several groups have now reported that all human DC subsets can efficiently cross-present several forms of antigen [reviewed by Ref. (57)]. Initially, CD $141^{+}$DCs isolated from human blood were described to better cross-present CMV protein pp65 in comparison to $\mathrm{CD}^{+} \mathrm{c}^{+} \mathrm{DCs}$ and pDCs from the same donor (67). It is important to note, however, that cross-presentation in vivo occurs rather in secondary lymphoid organs. A recent study has overcome the difficulties in isolating sufficient amounts of human DCs from lymphoid tissue and characterized in detail the cross-presentation properties of tonsil-resident DCs (73). An important finding of this study was that all tonsillar DC subsets (i.e., pDCs and the two populations of $\mathrm{cDCs}, \mathrm{CD} 1 \mathrm{c}^{+} \mathrm{DCs}$ and $\left.\mathrm{CD} 141^{+} \mathrm{DCs}\right)$ displayed comparable capacities to cross-present soluble antigens in contrast to macrophages, which lacked this ability. Interestingly, necrotic cells were phagocytosed and cross-presented by $\mathrm{CD} 1 \mathrm{c}^{+}$ DCs and CD $141^{+}$DCs with similar efficiency, while pDCs were poor at taking up necrotic particles, consequently resulting in inefficient cross-presentation. Tonsillar macrophages were found to be the most efficient at taking up dead cells, but despite this fact they completely failed to cross-present necrotic cells. Collectively, the ability to efficiently cross-present in humans seems less restricted to a specific DC subpopulation than as observed in mice. Along these lines, it has been shown that the cross-presentation properties of human DCs depend on the antigen uptake pathway and the ability of the pathway to route the antigen into an early endosomal compartment rather than on a specific DC subset $(74,75)$. $\mathrm{CD}_{141}{ }^{+} \mathrm{DCs}$ are superior cross-presenters compared to CD1c ${ }^{+}$ DCs only when the antigen is delivered via CD205, a receptor that preferentially targets antigens to late endo/lysosomal compartments. If antigen is targeted through CD40, CD1c ${ }^{+}$DCs are as efficient as CD141 ${ }^{+}$DCs. These findings argue that targeting one specific DC subset for the design of DC-based vaccines may not offer the presumed advantage.

The cross-presentation studies discussed above focused primarily on soluble antigen uptake and targeting antigen via several endocytic receptors. How does cross-presentation of immune complexes fit into this picture? Targeting DCs through IgG immune complexes has been proven to be superior to soluble immune complexes for inducing $\mathrm{CD}^{+} \mathrm{T}$ cell responses and as anti-tumor vaccines by utilizing murine bone marrow-derived DCs $(76,77)$. In addition, circulating specific antibodies have been shown to enhance systemic cross-priming by delivering immunecomplexed antigen to murine DCs in vivo (78). Notably in mice, immune-complexed antigen allows the $\mathrm{CD} 8 \alpha^{-}$DC subset, which has been proven to be very poor at presenting soluble antigen, to become potent cross-presenting cells (79). Interestingly, crosspresentation by CD8 $\alpha^{-}$DCs depends on activating Fc $\gamma$ receptors. Lack of the signal transducing $\gamma$-chain specifically abolishes presentation of immune-complexed antigen on MHC class I molecules but not on MHC class II molecules (79). Another remarkable feature regarding cross-presentation of immune complexes is their reliance on FcRn, an IgG binding receptor that is primarily located intracellularly and binds IgG independently from their Fc $\gamma$ receptor interaction sites (80). How FcRn promotes cross-presentation of immune complex is discussed later in more detail.

Our knowledge regarding cross-presentation of immunecomplexed antigen by human DC subsets is still very limited. The effects of $\mathrm{Fc} \gamma$ receptor antigen targeting on the efficiency of cross-presentation in human DCs were recently investigated using human cytomegalovirus (HCMV) pp65 as a protein antigen (81). In line with the data obtained from murine models, immune-complexed antigen is more efficiently cross-presented than comparable amounts of soluble antigen by human DCs. The enhanced cross-presentation capacity observed was not mediated by increased antigen uptake or induction of DC maturation through the immune-complexed antigen. The authors also demonstrated that both of the two major intracellular cross-presentation pathways (4), the cytosolic and 
the vacuolar/endosomal pathway, are involved in Fc $\gamma$ receptormediated uptake of immune complexes and their processing. Notably, monocyte-derived DCs as well as CD $141^{+}$DCs required antigen processing by both intracellular pathways. The finding that $\mathrm{CD}_{141}{ }^{+}$DCs, which are the human equivalent to $\mathrm{CD} 8 \alpha^{+} \mathrm{DCs}$, use both processing pathways for immune complexes points to unique features of human DCs. Murine CD $8 \alpha^{+}$DCs mainly use the cytosolic pathway to process antigen for cross-presentation, including the processing of immune complexes (82). Another difference to murine DCs is that the CD $141^{+}$DC subset proved to be superior to $\mathrm{CD}_{1} \mathrm{c}^{+} \mathrm{DCs}$ in cross-presenting pp65 immune complexes (81). These findings point to obvious differences between murine and human DC subsets regarding immune complexmediated cross-presentation. Since the human DCs were isolated from blood (81) and the murine DCs were isolated from the spleen $(79,80)$, it is possible that DCs from blood and lymphoid tissue generally differ in their cross-presentation capacities of immune complexes, which have similarly been observed for human DC subsets in response to soluble antigen as described above. In any case, the study by Flinsenberg et al. found that Fc $\gamma$ receptor targeting increases cross-presentation of HCMV antigen by human blood and tonsillar CD $141^{+}$DCs, which suggest that targeting of this DC subset with immune complexes might improve DC-based vaccination strategies. Another very important aspect of this study is the detailed characterization of Fc $\gamma$ receptor expression on human DC subsets. Although CD1c ${ }^{+}$DCs expressed overall higher levels of Fc $\gamma$ RII, CD $141^{+}$DCs seem to express higher levels of the activating Fc $\gamma$ RIIA relative to the inhibitory Fc $\gamma$ RIIB. Thus, this study clearly demonstrates that the overall expression level of one specific Fc $\gamma$ receptor does not determine the functional outcome, and that we need to consider the diversity of Fc $\gamma$ receptor expression by distinct DC subsets to evaluate the therapeutic potential of immune complex-mediated cross-presentation.

A further difference between mice and humans seems to be the cross-presentation capacity of pDCs. Several studies have reported that murine pDCs do not possess the ability to cross-present (8386) or that their capacity is insignificant when compared to cDCs (87). In contrast to mouse pDCs, human pDCs can efficiently cross-present antigen and induce $\mathrm{CD}^{+} \mathrm{T}$ cell responses (88-90). Human pDCs also express Fc $\gamma$ RIIA, and this receptor has been shown to mediate internalization of immunoglobulins bound to chromatin (91), Coxsackie virus (92), the model antigen KLH (93), and the tumor antigen NY-ESO-1 (94). In addition, the group of de Vries described that pDCs can use several receptor-targeted antigen uptake pathways, including the activating Fc $\gamma$ RIIA receptor, to target antibody-coated nanoparticles for cross-presentation. Although this study did not use classical immune complexes, together with a vaccination study in which pDCs significantly prolonged overall survival in melanoma patients (95), it supports the notion that pDCs are interesting targets for DC-based immunotherapeutic strategies.

Collectively, we should keep in mind that some of the observed differences between human and murine DC subsets regarding cross-presentation of immune complexes most likely stem from differences in their $\mathrm{Fc}$ receptor expression and from different binding affinities for IgG isotypes. Recently, various published and publicly available microarray data were compiled, and this mRNA collection provides an excellent overview of mouse and human Fcy receptor expression by DC subsets, monocytes, and macrophages (18). Overall, the Fc $\gamma$ receptor expression levels obtained by mRNA analysis correspond well with the surface expression levels acquired by flow cytometric analysis (FACS) (Table 2). For the future, it will be important to determine whether the Fcy receptor expression of human DC subsets isolated from blood also matches the expression on tissue-resident DCs from different organs.

\section{REGULATION OF FC $\gamma$ RECEPTOR EXPRESSION IMPACTS CROSS-PRESENTATION OF IMMUNE COMPLEXES}

Efficient cross-presentation for inducing protective immune responses against tumors or viruses is strongly governed by the ratio of activating versus inhibitory $\mathrm{Fc} \gamma$ receptors expressed on DCs. In addition to the DC subset, the maturation/activation state of DCs likely impacts their Fcy receptors expression pattern. The maturation/activation state of DCs is in general strongly influenced by the cytokine milieu of the microenvironment, and a considerable number of cytokines have been shown to regulate $\mathrm{F} c \gamma$ receptor expression in vitro. TGF- $\beta 1$ down-regulates surface expression Fc $\gamma$ RI and Fc $\gamma$ RIII on monocytes (99). IL-4, a cytokine associated with Th2-type immune responses, increases the expression of inhibitory Fc $\gamma$ RIIB. In contrast, the Th1-cytokine IFN$\gamma$ increases expression of activating $\mathrm{Fc}$ receptors on monocytes (100). Monocytes also have been shown to respond to IFN- $\gamma$ and TNF- $\alpha$ treatment with enhanced immune complex binding via $\mathrm{Fc} \gamma \mathrm{RI}$, even when saturated with pre-bound monomeric IgG (101). Cytokine-induced changes in Fc $\gamma$ receptor expression were also found using monocyte-derived DCs (96). Immature DCs generated with GM-CSF and IL-4 from monocytes express high amounts of inhibitory Fc $\gamma$ RIIB, which is down-regulated upon DC maturation induced by TNF- $\alpha$. The authors also showed that blood DCs activated with a cytokine cocktail containing TNF$\alpha$, IL-1 $\beta$, IL-6, and PGE2 induce more influenza-specific $\mathrm{CD}^{+}$ $\mathrm{T}$ memory cells via targeting of Fc $\gamma \mathrm{RI}$ and Fc $\gamma \mathrm{RIIA}$. Interestingly, crosslinking of inhibitory Fc $\gamma$ RIIB only reduced the crosspresentation ability of immature DCs but not of mature DCs. Treatment of mature blood DCs with IL-10, or a combination of IL-10 and IL13, was found to increase expression of Fc $\gamma$ RIIA and Fc $\gamma$ RIIB (96). To sum up, although we know that cytokines can modulate $\mathrm{F} c \gamma$ receptor expression, and that tumors create cytokine-rich microenvironments that involve the production of immunosuppressive as well as inflammatory cytokines to drive tumor progression $(102,103)$, our knowledge is very limited as to how cytokines from the tumor microenvironment affect cross-presentation of immune complexes by DCs. Thus, regarding anti-tumor therapy, this gap in knowledge might explain why the long-term therapeutic outcomes of immune complexbased strategies were not more successful, although efficient cross-presentation is induced by IgG-complexed antigens. One explanation could be that the tumor microenvironment promotes the induction of cross-tolerance by keeping the DCs in an immature state, which is associated with high expression levels of inhibitory Fc $\gamma$ RIIB. Another possible scenario would be that immune complex-mediated cross-presentation via activating Fc $\gamma$ receptors, which is known to result in inflammatory cytokine 
Table 2 | Fc $\gamma$ receptor expression by murine and human DC subsets.

\begin{tabular}{|c|c|c|c|c|c|c|c|}
\hline \multicolumn{4}{|c|}{ Human DCs } & \multicolumn{4}{|c|}{ Mouse DCs } \\
\hline \multirow[b]{3}{*}{ DC subset } & \multirow{2}{*}{\multicolumn{3}{|c|}{$\begin{array}{c}\text { Expression } \\
\text { High: }+++ \text {; low: }+\end{array}$}} & \multirow[b]{3}{*}{ DC subset } & \multirow{2}{*}{\multicolumn{3}{|c|}{$\begin{array}{c}\text { Expression } \\
\text { High: }+++ \text {; low: }+\end{array}$}} \\
\hline & & & & & & & \\
\hline & Receptor & FACS $^{a}$ & mRNA $^{b}$ & & Receptor & $\operatorname{FACS}(79,80,89)$ & mRNA $^{b}$ \\
\hline \multirow[t]{4}{*}{$\mathrm{CD}_{141}{ }^{+}\left(\mathrm{BDCA}^{+}, \mathrm{XCR}^{+}{ }^{+}\right)$} & $\mathrm{Fc} \gamma \mathrm{Rl}$ & - & $-/+$ & $\mathrm{CD}^{+}$ & $\mathrm{Fc} \gamma \mathrm{RI}$ & $-/+$ & + \\
\hline & Fc $\gamma R \| B$ & + & + & & Fc $\gamma R \| B$ & +++ & ++ \\
\hline & Fc $\gamma R I I I A$ & - & + & & Fc $\gamma R I I I$ & +++ & + \\
\hline & na & & & & FcyRIV & $-1+$ & + \\
\hline \multirow[t]{2}{*}{$\mathrm{CD}_{1 \mathrm{c}^{+}}\left(\mathrm{BDCA} 1^{+}, \mathrm{SIRP} \alpha^{+}\right)$} & $\mathrm{Fc} \gamma \mathrm{RI}$ & $+^{c}$ & + & $\mathrm{CD}^{-}$ & $\mathrm{Fc} \gamma \mathrm{RI}$ & $-/+$ & + \\
\hline & Fc $\gamma R \| A$ & ++ & +++ & & na & & \\
\hline \multirow[t]{5}{*}{$\mathrm{pDCs}$} & $\mathrm{Fc} \gamma \mathrm{RI}$ & - & $-/+$ & $\mathrm{pDCs}$ & $\mathrm{Fc} \gamma \mathrm{RI}$ & - & + \\
\hline & Fc $\gamma R \| A$ & ++ & + & & na & & \\
\hline & Fc $\gamma R \| B$ & + & + & & Fc $\gamma R \| B$ & + & ++ \\
\hline & Fc $\gamma \mathrm{RIIIA}$ & nd & + & & FcyRIII & - & + \\
\hline & na & & & & FcyRIV & - & + \\
\hline \multirow[t]{5}{*}{ Monocyte-derived DCs } & $\mathrm{Fc} \gamma \mathrm{RI}$ & + & + & Bone marrow-derived DCs & $\mathrm{Fc} \gamma \mathrm{RI}$ & $-/+$ & ++ \\
\hline & Fc $\gamma R \| A$ & ++ & +++ & & na & & \\
\hline & FcyRIIB & +++ & +++ & & Fc $\gamma R \| B$ & ++ & $-1+$ \\
\hline & Fc $\gamma \mathrm{R} I I I A$ & $-/+$ & + & & Fc $\gamma \mathrm{RIII}$ & ++ & ++ \\
\hline & na & & & & FcyRIV & $-1+$ & ++ \\
\hline
\end{tabular}

a Published surface expression determined by flow cytometric analysis (FACS) (81, 96-98).

${ }^{b}$ mRNA data from compiled microarrays (18).

${ }^{c} C D 1 C^{+} D C s$ isolated from blood; tonsillar CD1 $C^{+}: D C-/+$.

nd: not determined.

na: not applicable.

production by the DCs, actually contributes to an inflammatory tumor microenvironment, which fosters tumor progression by supporting, for example, angiogenesis. Therefore, future studies are needed that not only address which activating and inhibitory Fc $\gamma$ receptors are expressed by DC subsets, but also define how their expression patterns are regulated and which cytokines are induced by DC subsets after immune complex-mediated activation in vivo.

\section{FcRn - AN INTRACELLULAR RELAY RECEPTOR THAT GUIDES CROSS-PRESENTATION OF IgG-CONTAINING IMMUNE COMPLEXES}

In general, little is known about the intracellular mechanisms that are involved in processing of immune-complexed antigen for cross-presentation. Substantial evidence exists for an important role of FcRn in the cross-presentation of IgG-containing immune complexes. FcRn, which is an MHC class I-like molecule, was initially described only in intestinal epithelial cells of neonatal rodents, but it has since been shown to be expressed throughout life in several cell types, including human and rodent DCs (104-106). If CD8 $\alpha^{-}$DCs do not express FcRn because of genetic alterations, the cell loses its ability to efficiently crosspresent and fails to elicit $\mathrm{CD}^{+} \mathrm{T}$ cell responses (80). Elegant studies showed that FcRn regulates the intracellular sorting of IgG immune complexes in CD8 $\alpha^{-}$DCs. In contrast to CD $8 \alpha^{+}$ DCs where the endosomes are buffered around the neutral $\mathrm{pH}$ of 7.0 that prevents antigen degradation and promotes crosspresentation, $\mathrm{Fc} \gamma$ receptors in $\mathrm{CD} 8 \alpha^{-}$DCs traffic antigens into acidic compartments ( $\mathrm{pH}$ 6.0). The acidic environment is, by itself, not favorable for cross-presentation; however, it favors the binding of IgG to FcRn, and thus the model proposes that FcRn traps immune-complexed antigen and protects it from degradation 
within an acidic loading compartment. The study also showed that in parallel to antigen entry into the FcRn-positive compartment, key components of the phagosome-to-cytosol cross-presentation machinery are rapidly recruited to the endo/lysosome. Vesicles that contained IgG-opsonized particles or IgG immune complexes rapidly acquired greater quantities of vacuolar ATPase (V-ATPase), gp91phox, and Rab27a than those that resulted from internalization of IgG mutants that cannot interact with FcRn. Consistent with this concept, it was described that the presence of FcRn also affects the oxidation state as well as the acidification of vesicles. Inhibitor studies demonstrated that FcRn-mediated cross-presentation depends on the proteasome as well as Sec61 $\alpha$, which is indicative for the cytosolic cross-presentation pathway. Since insulin-regulated amino peptidase (IRAP) enrichment was not depicted in FcRn-positive IgG immune complex-containing vesicles, and cathepsin inhibitors did not abrogate IgG immune complex cross-presentation, the authors concluded that the alternative vacuolar pathway was not involved. In summary, this study suggests that FcRn binding of IgG immune complexes enables a slower and more controlled antigenic degradation in CD8 $\alpha^{-}$DCs, thereby permitting this population of DCs to become efficient cross-presenting cells.

The most compelling evidence for the exceptional importance of FcRn for cross-presentation of IgG immune complexes and IgGopsonized particles is derived from in vivo studies that analyzed the effects of FcRn-deficiency on chronic intestinal inflammation and colonic cancer $(107,108)$. In a chemically induced chronic colitis model, which is associated with generating high levels of anti-bacterial antibodies that enter the host as IgG immune complexes, Baker et al. demonstrated that FcRn-dependent crosspresentation is carried out by $\mathrm{CD} 8 \alpha^{-}$DCs in vivo, leading to greater levels of cytotoxic $\mathrm{T}$ cell activation during the course of colitis. In a recent study, the same group focused on the impact of FcRn on tumor development, clearly demonstrating the importance of this molecule for anti-tumor immune surveillance (108). The authors found that the DC-specific deletion of FcRn leads to increased tumor burden in experimental models of colon cancer and lung metastasis. Strikingly, this study also demonstrated that colon cancer patients with higher numbers of FcRn-positive DCs in the adjacent tumor tissue had significantly better prognoses, confirming the crucial role of FcRn and demonstrating the vital role of cross-presentation of IgG immune complexes in anti-tumor immunity in general. It will now be of utmost importance to elucidate the details of the intracellular mechanism of this process to evaluate whether the pathway can be employed for cancer immunotherapy.

\section{CONCLUSION}

Although ample evidence suggests that $\mathrm{Fc} \gamma$ receptor targeting through immune complexes allows for more efficient crosspresentation compared to soluble antigen, it still needs to be proven which advantages it may have over targeting of other endocytic receptors on DCs, especially in vivo. In this respect, it is very important to continue developing better murine models which more accurately reflect the human immune system. The recently published humanized Fc $\gamma \mathrm{R}$ mouse strain is here a promising step in the right direction. For therapeutic manipulations, we also need to better understand how $\mathrm{Fc} \gamma$ receptor expression by DCs is regulated. Can we use cytokines and/or TLR ligands to modulate the ratio of inhibitory versus activating $\mathrm{Fc} \gamma$ receptors expressed by DC subsets to improve therapeutic strategies? TLR2 ligands, for example, have been shown to increase expression of inhibitory Fc $\gamma$ RIIB in macrophages (109), a consequence not desirable in the context of viral or tumor vaccine development. Furthermore, how does the size of immune complexes influence cross-presentation? How does the antibody to antigen ratio in immune complexes influence cross-presentation? Indeed, it has been shown that immune complex size and glycosylation on IgG impact the binding to human $\mathrm{Fc} \gamma$ receptors (110). In summary, it is fair to conclude that many important questions remain open and need to be addressed. Irrespectively, cross-presentation of immune complexes represents an exciting potential pathway to improve DC-based vaccination strategies for anti-viral as well as anti-tumor therapy.

\section{ACKNOWLEDGMENTS}

This work was supported by grants from the National Institutes of Health: K01DK093597 (to Barbara Platzer) and AI075037 (to Edda Fiebiger). This work was also supported by the Harvard Digestive Diseases Center Grant P30DK034854.

\section{REFERENCES}

1. Sigal LJ, Crotty S, Andino R, Rock KL. Cytotoxic T-cell immunity to virusinfected non-haematopoietic cells requires presentation of exogenous antigen. Nature (1999) 398:77-80. doi:10.1038/18038

2. Jung S, Unutmaz D, Wong P, Sano G, de Los Santos K, Sparwasser T, et al. In vivo depletion of CD11c+ dendritic cells abrogates priming of CD8+ $\mathrm{T}$ cells by exogenous cell-associated antigens. Immunity (2002) 17:211-20. doi:10.1016/S1074-7613(02)00365-5

3. Winau F, Weber S, Sad S, de Diego J, Hoops SL, Breiden B, et al. Apoptotic vesicles crossprime CD8 T cells and protect against tuberculosis. Immunity (2006) 24:105-17. doi:10.1016/j.immuni.2005.12.001

4. Joffre OP, Segura E, Savina A, Amigorena S. Cross-presentation by dendritic cells. Nat Rev Immunol (2012) 12:557-69. doi:10.1038/nri3254

5. Apetoh L, Locher C, Ghiringhelli F, Kroemer G, Zitvogel L. Harnessing dendritic cells in cancer. Semin Immunol (2011) 23:42-9. doi:10.1016/j.smim.2011. 01.003

6. Andersen BM, Ohlfest JR. Increasing the efficacy of tumor cell vaccines by enhancing cross priming. Cancer Lett (2012) 325:155-64. doi:10.1016/j.canlet. 2012.07.012

7. Bonifaz L, Bonnyay D, Mahnke K, Rivera M, Nussenzweig MC, Steinman RM. Efficient targeting of protein antigen to the dendritic cell receptor DEC-205 in the steady state leads to antigen presentation on major histocompatibility complex class I products and peripheral CD8+ T cell tolerance. J Exp Med (2002) 196:1627-38. doi:10.1084/jem.20021598

8. Tacken PJ, Figdor CG. Targeted antigen delivery and activation of dendritic cells in vivo: steps towards cost effective vaccines. Semin Immunol (2011) 23:12-20. doi:10.1016/j.smim.2011.01.001

9. Caminschi I, Maraskovsky E, Heath WR. Targeting dendritic cells in vivo for cancer therapy. Front Immunol (2012) 3:13. doi:10.3389/fimmu.2012.00013

10. Kreutz M, Tacken PJ, Figdor CG. Targeting dendritic cells - why bother? Blood (2013) 121:2836-44. doi:10.1182/blood-2012-09-452078

11. de Vries IJ, Krooshoop DJ, Scharenborg NM, Lesterhuis WJ, Diepstra JH, Van Muijen GN, et al. Effective migration of antigen-pulsed dendritic cells to lymph nodes in melanoma patients is determined by their maturation state. Cancer Res (2003) 63:12-7.

12. Sancho D, Mourao-Sa D, Joffre OP, Schulz O, Rogers NC, Pennington DJ, et al. Tumor therapy in mice via antigen targeting to a novel, DC-restricted C-type lectin. J Clin Invest (2008) 118:2098-110. doi:10.1172/JCI34584

13. Hemmi H, Zaidi N, Wang B, Matos I, Fiorese C, Lubkin A, et al. Treml4, an Ig superfamily member, mediates presentation of several antigens to $\mathrm{T}$ cells 
in vivo, including protective immunity to HER2 protein. J Immunol (2012) 188:1147-55. doi:10.4049/jimmunol.1102541

14. Tacken PJ, de Vries IJ, Torensma R, Figdor CG. Dendritic-cell immunotherapy: from ex vivo loading to in vivo targeting. Nat Rev Immunol (2007) 7:790-802. doi:10.1038/nri2173

15. Eubel J, Enk AH. Dendritic cell vaccination as a treatment modality for melanoma. Expert Rev Anticancer Ther (2009) 9:1631-42. doi:10.1586/era. 09.139

16. Robson NC, Hoves S, Maraskovsky E, Schnurr M. Presentation of tumour antigens by dendritic cells and challenges faced. Curr Opin Immunol (2010) 22:137-44. doi:10.1016/j.coi.2010.01.002

17. Baker K, Rath T, Lencer WI, Fiebiger E, Blumberg RS. Cross-presentation of IgG-containing immune complexes. Cell Mol Life Sci (2013) 70:1319-34. doi:10.1007/s00018-012-1100-8

18. Guilliams M, Bruhns P, Saeys Y, Hammad H, Lambrecht BN. The function of Fcgamma receptors in dendritic cells and macrophages. Nat Rev Immunol (2014) 14:94-108. doi:10.1038/nri3582

19. Clynes R, Takechi Y, Moroi Y, Houghton A, Ravetch JV. Fc receptors are required in passive and active immunity to melanoma. Proc Natl Acad Sci U S A (1998) 95:652-6. doi:10.1073/pnas.95.2.652

20. Celis E, Chang TW. HBsAg-serum protein complexes stimulate immune T lymphocytes more efficiently than do pure HBsAg. Hepatology (1984) 4:1116-23. doi:10.1002/hep.1840040604

21. Celis E, Zurawski VR Jr, Chang TW. Regulation of T-cell function by antibodies: enhancement of the response of human T-cell clones to hepatitis B surface antigen by antigen-specific monoclonal antibodies. Proc Natl Acad Sci U S A (1984) 81:6846-50. doi:10.1073/pnas.81.21.6846

22. Snider DP, Segal DM. Targeted antigen presentation using crosslinked antibody heteroaggregates. J Immunol (1987) 139:1609-16.

23. Vasovic LV, Dyall R, Clynes RA, Ravetch JV, Nikolic-Zugic J. Synergy between an antibody and CD8+ cells in eliminating an established tumor. Eur J Immunol (1997) 27:374-82. doi:10.1002/eji.1830270206

24. Regnault A, Lankar D, Lacabanne V, Rodriguez A, Thery C, Rescigno M, et al. Fcgamma receptor-mediated induction of dendritic cell maturation and major histocompatibility complex class I-restricted antigen presentation after immune complex internalization. J Exp Med (1999) 189:371-80. doi:10.1084/jem.189.2.371

25. Rodriguez A, Regnault A, Kleijmeer M, Ricciardi-Castagnoli P, Amigorena S. Selective transport of internalized antigens to the cytosol for MHC class I presentation in dendritic cells. Nat Cell Biol (1999) 1:362-8. doi:10.1038/14058

26. Schuurhuis DH, Ioan-Facsinay A, Nagelkerken B, Van Schip JJ, Sedlik C, Melief $\mathrm{CJ}$, et al. Antigen-antibody immune complexes empower dendritic cells to efficiently prime specific CD8+ CTL responses in vivo. J Immunol (2002) 168:2240-6.

27. Machy P, Serre K, Leserman L. Class I-restricted presentation of exogenous antigen acquired by Fcgamma receptor-mediated endocytosis is regulated in dendritic cells. Eur J Immunol (2000) 30:848-57. doi:10.1002/1521-4141(200003) 30:3<848::AID-IMMU848>3.0.CO;2-Q

28. Dhodapkar KM, Krasovsky J, Williamson B, Dhodapkar MV. Antitumor monoclonal antibodies enhance cross-presentation of cellular antigens and the generation of myeloma-specific killer T cells by dendritic cells. J Exp Med (2002) 195:125-33. doi:10.1084/jem.20011097

29. Nimmerjahn F, Ravetch JV. FcgammaRs in health and disease. Curr Top Microbiol Immunol (2011) 350:105-25. doi:10.1007/82_2010_86

30. Hulett MD, Hogarth PM. Molecular basis of Fc receptor function. Adv Immunol (1994) 57:1-127. doi:10.1016/S0065-2776(08)60671-9

31. Ravetch JV. Fc receptor. In: Paul WE, editor. Fundamental Immunology. Philadelphia, PA: Lippincott Williams \& Wilkins (2003). p. 685-700.

32. Nimmerjahn F, Ravetch JV. Fc $\gamma$ receptors: old friends and new family members. Immunity (2006) 24:19-28. doi:10.1016/j.immuni.2005.11.010

33. Nimmerjahn F, Ravetch JV. Fc $\gamma$ receptors as regulators of immune responses. Nat Rev Immunol (2008) 8:34-47. doi:10.1038/nri2206

34. Desai DD, Harbers SO, Flores M, Colonna L, Downie MP, Bergtold A, et al. Fc gamma receptor IIB on dendritic cells enforces peripheral tolerance by inhibiting effector T cell responses. J Immunol (2007) 178:6217-26.

35. Harbers SO, Crocker A, Catalano G, D'Agati V, Jung S, Desai DD, et al. Antibody-enhanced cross-presentation of self antigen breaks $\mathrm{T}$ cell tolerance. J Clin Invest (2007) 117:1361-9. doi:10.1172/JCI29470
36. Kalergis AM, Ravetch JV. Inducing tumor immunity through the selective engagement of activating Fcgamma receptors on dendritic cells. J Exp Med (2002) 195:1653-9. doi:10.1084/jem.20020338

37. Boruchov AM, Heller G, Veri MC, Bonvini E, Ravetch JV, Young JW. Activating and inhibitory IgG Fc receptors on human DCs mediate opposing functions. J Clin Invest (2005) 115:2914-23. doi:10.1172/JCI24772

38. Dhodapkar KM, Dhodapkar MV. Recruiting dendritic cells to improve antibody therapy of cancer. Proc Natl Acad Sci U S A (2005) 102:6243-4. doi:10.1073/pnas.0502547102

39. van Montfoort NT, Hoen PA, Mangsbo SM, Camps MG, Boross P, Melief CJ, et al. Fcgamma receptor IIb strongly regulates Fcgamma receptor-facilitated $\mathrm{T}$ cell activation by dendritic cells. J Immunol (2012) 189:92-101. doi:10.4049/ jimmunol.1103703

40. Boross P, Arandhara VL, Martin-Ramirez J, Santiago-Raber ML, Carlucci F, Flierman R, et al. The inhibiting Fc receptor for IgG, FcgammaRIIB, is a modifier of autoimmune susceptibility. J Immunol (2011) 187:1304-13. doi:10.4049/jimmunol.1101194

41. Bruhns P. Properties of mouse and human IgG receptors and their contribution to disease models. Blood (2012) 119:5640-9. doi:10.1182/blood-2012-01380121

42. Bruhns P, Iannascoli B, England P, Mancardi DA, Fernandez N, Jorieux S, et al. Specificity and affinity of human Fcgamma receptors and their polymorphic variants for human IgG subclasses. Blood (2009) 113:3716-25. doi:10.1182/blood-2008-09-179754

43. Vitetta ES, Ghetie VF. Immunology. Considering therapeutic antibodies. Science (2006) 313:308-9. doi:10.1126/science.1130482

44. Smith P, Dilillo DJ, Bournazos S, Li F, Ravetch JV. Mouse model recapitulating human Fcgamma receptor structural and functional diversity. Proc Natl Acad Sci U S A (2012) 109:6181-6. doi:10.1073/pnas.1203954109

45. van Egmond M, Van Vuuren AJ, Morton HC, Van Spriel AB, Shen L, Hofhuis FM, et al. Human immunoglobulin A receptor (FcalphaRI, CD89) function in transgenic mice requires both FcR gamma chain and CR3 (CD11b/CD18). Blood (1999) 93:4387-94.

46. Dehlink E, Baker AH, Yen E, Nurko S, Fiebiger E. Relationships between levels of serum IgE, cell-bound IgE, and IgE-receptors on peripheral blood cells in a pediatric population. PLoS One (2010) 5:e12204. doi:10.1371/journal.pone. 0012204

47. Platzer B, Dehlink E, Turley SJ, Fiebiger E. How to connect an IgE-driven response with CTL activity? Cancer Immunol Immunother (2012) 61:1521-5. doi:10.1007/s00262-011-1127-y

48. Vasudev M, Cheung DS, Pincsak H, Li SH, Yan K, Simpson P, et al. Expression of high-affinity $\mathrm{IgE}$ receptor on human peripheral blood dendritic cells in children. PLoS One (2012) 7:e32556. doi:10.1371/journal. pone.0032556

49. Salmon JE, Edberg JC, Brogle NL, Kimberly RP. Allelic polymorphisms of human Fc gamma receptor IIA and Fc gamma receptor IIIB. Independent mechanisms for differences in human phagocyte function. J Clin Invest (1992) 89:1274-81. doi:10.1172/JCI115712

50. Sanders LA, van de Winkel JG, Rijkers GT, Voorhorst-Ogink MM, de Haas M, Capel PJ, et al. Fc gamma receptor IIa (CD32) heterogeneity in patients with recurrent bacterial respiratory tract infections. J Infect Dis (1994) 170:854-61. doi:10.1093/infdis/170.4.854

51. van Sorge NM, van der Pol WL, van de Winkel JG. FcgammaR polymorphisms: implications for function, disease susceptibility and immunotherapy. Tissue Antigens (2003) 61:189-202. doi:10.1034/j.1399-0039.2003.00037.x

52. Shashidharamurthy R, Zhang F, Amano A, Kamat A, Panchanathan R, Ezekwudo D, et al. Dynamics of the interaction of human IgG subtype immune complexes with cells expressing $\mathrm{R}$ and $\mathrm{H}$ allelic forms of a low-affinity Fc gamma receptor CD32A. J Immunol (2009) 183:8216-24. doi:10.4049/ jimmunol.0902550

53. Pandey JP, Kistner-Griffin E, Namboodiri AM, Black L, Jobim M. Suggestive evidence that $\mathrm{Fc}$ variants of IgG2 and FcgammaRIIa loci interact to contribute to the risk of prostate cancer. Hum Immunol (2013) 74:1656-8. doi:10.1016/j.humimm.2013.08.280

54. Pandey JP, Namboodiri AM, Kistner-Griffin E. A genetic variant of FcgammaRIIIa is strongly associated with humoral immunity to cyclin B1 in African American patients with prostate cancer. Immunogenetics (2013) 65:91-6. doi:10.1007/s00251-012-0660-y 
55. Pandey JP, Namboodiri AM, Kistner-Griffin E, Iwasaki M, Kasuga Y, Hamada GS, et al. Racially restricted contribution of immunoglobulin Fcgamma and Fcgamma receptor genotypes to humoral immunity to human epidermal growth factor receptor 2 in breast cancer. Clin Exp Immunol (2013) 171:273-7. doi:10.1111/cei.12018

56. Anthony RM, Wermeling F, Ravetch JV. Novel roles for the IgG Fc glycan. Ann N Y Acad Sci (2012) 1253:170-80. doi:10.1111/j.1749-6632.2011.06305.x

57. Segura E, Amigorena S. Cross-presentation by human dendritic cell subsets. Immunol Lett (2013) 158:73-8. doi:10.1016/j.imlet.2013.12.001

58. Liu K, Nussenzweig MC. Origin and development of dendritic cells. Immunol Rev (2010) 234:45-54. doi:10.1111/j.0105-2896.2009.00879.x

59. Haniffa M, Collin M, Ginhoux F. Ontogeny and functional specialization of dendritic cells in human and mouse. Adv Immunol (2013) 120:1-49. doi:10.1016/B978-0-12-417028-5.00001-6

60. Merad M, Sathe P, Helft J, Miller J, Mortha A. The dendritic cell lineage: ontogeny and function of dendritic cells and their subsets in the steady state and the inflamed setting. Annu Rev Immunol (2013) 31:563-604. doi:10.1146/ annurev-immunol-020711-074950

61. Robbins SH, Walzer T, Dembele D, Thibault C, Defays A, Bessou G, et al. Novel insights into the relationships between dendritic cell subsets in human and mouse revealed by genome-wide expression profiling. Genome Biol (2008) 9:R17. doi:10.1186/gb-2008-9-1-r17

62. Crozat K, Guiton R, Guilliams M, Henri S, Baranek T, Schwartz-Cornil I, et al. Comparative genomics as a tool to reveal functional equivalences between human and mouse dendritic cell subsets. Immunol Rev (2010) 234:177-98. doi:10.1111/j.0105-2896.2009.00868.x

63. den Haan JM, Lehar SM, Bevan MJ. CD8(+) but not CD8(-) dendritic cells cross-prime cytotoxic T cells in vivo. J Exp Med (2000) 192:1685-96. doi:10.1084/jem.192.12.1685

64. Iyoda T, Shimoyama S, Liu K, Omatsu Y, Akiyama Y, Maeda Y, et al. The CD8+ dendritic cell subset selectively endocytosis dying cells in culture and in vivo. J Exp Med (2002) 195:1289-302. doi:10.1084/jem.20020161

65. Schulz O, Reis E, Sousa C. Cross-presentation of cell-associated antigens by CD8alpha+ dendritic cells is attributable to their ability to internalize dead cells. Immunology (2002) 107:183-9. doi:10.1046/j.1365-2567.2002.01513.x

66. Schnorrer P, Behrens GM, Wilson NS, Pooley JL, Smith CM, El-Sukkari D, et al. The dominant role of CD8+ dendritic cells in cross-presentation is not dictated by antigen capture. Proc Natl Acad Sci U S A (2006) 103:10729-34. doi:10.1073/pnas.0601956103

67. Bachem A, Guttler S, Hartung E, Ebstein F, Schaefer M, Tannert A, et al. Superior antigen cross-presentation and XCR1 expression define human CD11c+CD141+ cells as homologues of mouse CD8+ dendritic cells. J Exp Med (2010) 207:1273-81. doi:10.1084/jem.20100348

68. Jongbloed SL, Kassianos AJ, Mcdonald KJ, Clark GJ, Ju X, Angel CE, et al. Human CD141+ (BDCA-3)+ dendritic cells (DCs) represent a unique myeloid DC subset that cross-presents necrotic cell antigens. J Exp Med (2010) 207:1247-60. doi:10.1084/jem.20092140

69. Poulin LF, Salio M, Griessinger E, Anjos-Afonso F, Craciun L, Chen JL, et al. Characterization of human DNGR-1+ BDCA3+ leukocytes as putative equivalents of mouse CD8alpha+ dendritic cells. J Exp Med (2010) 207:1261-71. doi:10.1084/jem.20092618

70. Mittag D, Proietto AI, Loudovaris T, Mannering SI, Vremec D, Shortman K, et al. Human dendritic cell subsets from spleen and blood are similar in phenotype and function but modified by donor health status. J Immunol (2011) 186:6207-17. doi:10.4049/jimmunol.1002632

71. van de Ven R, van den Hout MF, Lindenberg JJ, Sluijter BJ, Van Leeuwen PA, Lougheed SM, et al. Characterization of four conventional dendritic cell subsets in human skin-draining lymph nodes in relation to T-cell activation. Blood (2011) 118:2502-10. doi:10.1182/blood-2011-03-344838

72. Haniffa M, Shin A, Bigley V, Mcgovern N, Teo P, See P, et al. Human tissues contain CD141hi cross-presenting dendritic cells with functional homology to mouse CD103+ nonlymphoid dendritic cells. Immunity (2012) 37:60-73. doi:10.1016/j.immuni.2012.04.012

73. Segura E, Durand M, Amigorena S. Similar antigen cross-presentation capacity and phagocytic functions in all freshly isolated human lymphoid organresident dendritic cells. J Exp Med (2013) 210:1035-47. doi:10.1084/jem. 20121103
74. Chatterjee B, Smed-Sorensen A, Cohn L, Chalouni C, Vandlen R, Lee BC, et al. Internalization and endosomal degradation of receptor-bound antigens regulate the efficiency of cross presentation by human dendritic cells. Blood (2012) 120:2011-20. doi:10.1182/blood-2012-01-402370

75. Cohn L, Chatterjee B, Esselborn F, Smed-Sorensen A, Nakamura N, Chalouni $\mathrm{C}$, et al. Antigen delivery to early endosomes eliminates the superiority of human blood BDCA3+ dendritic cells at cross presentation. J Exp Med (2013) 210:1049-63. doi:10.1084/jem.20121251

76. de Jong JM, Schuurhuis DH, Ioan-Facsinay A, van der Voort EI, Huizinga TW, Ossendorp F, et al. Murine Fc receptors for IgG are redundant in facilitating presentation of immune complex derived antigen to CD8+ T cells in vivo. $\mathrm{Mol}$ Immunol (2006) 43:2045-50. doi:10.1016/j.molimm.2006.01.002

77. Schuurhuis DH, Van Montfoort N, Ioan-Facsinay A, Jiawan R, Camps M, Nouta $\mathrm{J}$, et al. Immune complex-loaded dendritic cells are superior to soluble immune complexes as antitumor vaccine. J Immunol (2006) 176:4573-80.

78. van Montfoort N, Mangsbo SM, Camps MG, Van Maren WW, Verhaart IE, Waisman A, et al. Circulating specific antibodies enhance systemic crosspriming by delivery of complexed antigen to dendritic cells in vivo. Eur J Immunol (2012) 42:598-606. doi:10.1002/eji.201141613

79. den Haan JM, Bevan MJ. Constitutive versus activation-dependent crosspresentation of immune complexes by CD8(+) and CD8(-) dendritic cells in vivo. J Exp Med (2002) 196:817-27. doi:10.1084/jem.20020295

80. Baker K, Qiao SW, Kuo TT, Aveson VG, Platzer B, Andersen JT, et al. Neonatal Fc receptor for IgG $(\mathrm{FcRn})$ regulates cross-presentation of IgG immune complexes by CD8-CD11b+ dendritic cells. Proc Natl Acad Sci U S A (2011) 108:9927-32. doi:10.1073/pnas.1019037108

81. Flinsenberg TW, Compeer EB, Koning D, Klein M, Amelung FJ, Van Baarle D, et al. Fcgamma receptor antigen targeting potentiates cross-presentation by human blood and lymphoid tissue BDCA-3+ dendritic cells. Blood (2012) 120:5163-72. doi:10.1182/blood-2012-06-434498

82. Segura E, Albiston AL, Wicks IP, Chai SY, Villadangos JA. Different crosspresentation pathways in steady-state and inflammatory dendritic cells. Proc Natl Acad Sci U S A (2009) 106:20377-81. doi:10.1073/pnas.0910295106

83. Salio M, Palmowski MJ, Atzberger A, Hermans IF, Cerundolo V. CpG-matured murine plasmacytoid dendritic cells are capable of in vivo priming of functional CD8 T cell responses to endogenous but not exogenous antigens. J Exp Med (2004) 199:567-79. doi:10.1084/jem.20031059

84. Sapoznikov A, Fischer JA, Zaft T, Krauthgamer R, Dzionek A, Jung S. Organdependent in vivo priming of naive $\mathrm{CD} 4+$, but not $\mathrm{CD} 8+, \mathrm{T}$ cells by plasmacytoid dendritic cells. J Exp Med (2007) 204:1923-33. doi:10.1084/jem. 20062373

85. Jaehn PS, Zaenker KS, Schmitz J, Dzionek A. Functional dichotomy of plasmacytoid dendritic cells: antigen-specific activation of $\mathrm{T}$ cells versus production of type I interferon. Eur J Immunol (2008) 38:1822-32. doi:10. 1002/eji.200737552

86. Flores M, Desai DD, Downie M, Liang B, Reilly MP, Mckenzie SE, et al. Dominant expression of the inhibitory FcgammaRIIB prevents antigen presentation by murine plasmacytoid dendritic cells. J Immunol (2009) 183:7129-39. doi:10.4049/jimmunol.0901169

87. Shinohara ML, Lu L, Bu J, Werneck MB, Kobayashi KS, Glimcher LH, et al. Osteopontin expression is essential for interferon-alpha production by plasmacytoid dendritic cells. Nat Immunol (2006) 7:498-506. doi:10.1038/ni1327

88. Di Pucchio T, Chatterjee B, Smed-Sorensen A, Clayton S, Palazzo A, Montes $\mathrm{M}$, et al. Direct proteasome-independent cross-presentation of viral antigen by plasmacytoid dendritic cells on major histocompatibility complex class I. Nat Immunol (2008) 9:551-7. doi:10.1038/ni.1602

89. Tel J, Schreibelt G, Sittig SP, Mathan TS, Buschow SI, Cruz LJ, et al. Human plasmacytoid dendritic cells efficiently cross-present exogenous Ags to CD8+ T cells despite lower Ag uptake than myeloid dendritic cell subsets. Blood (2013) 121:459-67. doi:10.1182/blood-2012-06-435644

90. Tel J, Sittig SP, Blom RA, Cruz LJ, Schreibelt G, Figdor CG, et al. Targeting uptake receptors on human plasmacytoid dendritic cells triggers antigen crosspresentation and robust type I IFN secretion. J Immunol (2013) 191:5005-12. doi:10.4049/jimmunol.1300787

91. Means TK, Latz E, Hayashi F, Murali MR, Golenbock DT, Luster AD. Human lupus autoantibody-DNA complexes activate DCs through cooperation of CD32 and TLR9. J Clin Invest (2005) 115:407-17. doi:10.1172/JCI23025 
92. Wang B, Chen G, Zhou J, Wu P, Luo D, Huang X, et al. Deletion of the intracellular domain of Coxsackie and adenovirus receptor (CAR) enhances the expression of itself and boosts the efficiency of current adenovirus-mediated gene therapy in ovarian cancer cell lines in vitro. Cancer Lett (2007) 248:299-307. doi:10.1016/j.canlet.2006.08.002

93. Benitez-Ribas D, Adema GJ, Winkels G, Klasen IS, Punt CJ, Figdor CG, et al. Plasmacytoid dendritic cells of melanoma patients present exogenous proteins to CD4+ T cells after Fc gamma RII-mediated uptake. J Exp Med (2006) 203:1629-35. doi:10.1084/jem.20052364

94. Schnurr M, Chen Q, Shin A, Chen W, Toy T, Jenderek C, et al. Tumor antigen processing and presentation depend critically on dendritic cell type and the mode of antigen delivery. Blood (2005) 105:2465-72. doi:10.1182/blood2004-08-3105

95. Tel J, Aarntzen EH, Baba T, Schreibelt G, Schulte BM, Benitez-Ribas D, et al. Natural human plasmacytoid dendritic cells induce antigen-specific T-cell responses in melanoma patients. Cancer Res (2013) 73:1063-75. doi:10.1158/ 0008-5472.CAN-12-2583

96. Liu Y, Gao X, Masuda E, Redecha PB, Blank MC, Pricop L. Regulated expression of FcgammaR in human dendritic cells controls cross-presentation of antigen-antibody complexes. J Immunol (2006) 177:8440-7.

97. Benitez-Ribas D, Tacken P, Punt CJ, de Vries IJ, Figdor CG. Activation of human plasmacytoid dendritic cells by TLR9 impairs Fc gammaRII-mediated uptake of immune complexes and presentation by MHC class II. J Immunol (2008) 181:5219-24.

98. Dobel T, Kunze A, Babatz J, Trankner K, Ludwig A, Schmitz M, et al. FcgammaRIII (CD16) equips immature 6-sulfo LacNAc-expressing dendritic cells (slanDCs) with a unique capacity to handle IgG-complexed antigens. Blood (2013) 121:3609-18. doi:10.1182/blood-2012-08-447045

99. Tridandapani S, Wardrop R, Baran CP, Wang Y, Opalek JM, Caligiuri MA, et al. TGF-beta 1 suppresses [correction of supresses] myeloid Fc gamma receptor function by regulating the expression and function of the common gammasubunit. J Immunol (2003) 170:4572-7.

100. Pricop L, Redecha P, Teillaud JL, Frey J, Fridman WH, Sautes-Fridman C, et al. Differential modulation of stimulatory and inhibitory Fc gamma receptors on human monocytes by Th1 and Th2 cytokines. J Immunol (2001) 166: 531-7.

101. van der Poel CE, Karssemeijer RA, Boross P, van der Linden JA, Blokland M, van de Winkel JG, et al. Cytokine-induced immune complex binding to the high-affinity IgG receptor, FcgammaRI, in the presence of monomeric IgG. Blood (2010) 116:5327-33. doi:10.1182/blood-2010-04-280214

102. Lippitz BE. Cytokine patterns in patients with cancer: a systematic review. Lancet Oncol (2013) 14:e218-28. doi:10.1016/S1470-2045(12)70582-X
103. Pickup M, Novitskiy S, Moses HL. The roles of TGFbeta in the tumour microenvironment. Nat Rev Cancer (2013) 13:788-99. doi:10.1038/nrc3603

104. Simister NE, Mostov KE. An Fc receptor structurally related to MHC class I antigens. Nature (1989) 337:184-7. doi:10.1038/337184a0

105. Kuo TT, Baker K, Yoshida M, Qiao SW, Aveson VG, Lencer WI, et al. Neonatal Fc receptor: from immunity to therapeutics. J Clin Immunol (2010) 30:777-89. doi:10.1007/s10875-010-9468-4

106. Rath T, Kuo TT, Baker K, Qiao SW, Kobayashi K, Yoshida M, et al. The immunologic functions of the neonatal Fc receptor for IgG. J Clin Immunol (2013) 33(Suppl 1):S9-17. doi:10.1007/s10875-012-9768-y

107. Kobayashi K, Qiao SW, Yoshida M, Baker K, Lencer WI, Blumberg RS. An FcRn-dependent role for anti-flagellin immunoglobulin $\mathrm{G}$ in pathogenesis of colitis in mice. Gastroenterology (2009) 137:1746e-56e. doi:10.1053/j.gastro. 2009.07.059

108. Baker K, Rath T, Flak MB, Arthur JC, Chen Z, Glickman JN, et al. Neonatal $\mathrm{Fc}$ receptor expression in dendritic cells mediates protective immunity against colorectal cancer. Immunity (2013) 39:1095-107. doi:10.1016/j.immuni.2013. 11.003

109. Abdollahi-Roodsaz S, Koenders MI, Walgreen B, Bolscher J, Helsen MM, van den Bersselaar LA, et al. Toll-like receptor 2 controls acute immune complexdriven arthritis in mice by regulating the inhibitory Fcgamma receptor IIB. Arthritis Rheum (2013) 65:2583-93. doi:10.1002/art.38087

110. Lux A, Yu X, Scanlan CN, Nimmerjahn F. Impact of immune complex size and glycosylation on IgG binding to human FcgammaRs. J Immunol (2013) 190:4315-23. doi:10.4049/jimmunol.1200501

Conflict of Interest Statement: The authors declare that the research was conducted in the absence of any commercial or financial relationships that could be construed as a potential conflict of interest.

Received: 01 February 2014; paper pending published: 03 March 2014; accepted: 19 March 2014; published online: 01 April 2014.

Citation: Platzer B, Stout M and Fiebiger E (2014) Antigen cross-presentation of immune complexes. Front. Immunol. 5:140. doi: 10.3389/fimmu.2014.00140

This article was submitted to Antigen Presenting Cell Biology, a section of the journal Frontiers in Immunology.

Copyright ( $(2014$ Platzer, Stout and Fiebiger. This is an open-access article distributed under the terms of the Creative Commons Attribution License (CC BY). The use, distribution or reproduction in other forums is permitted, provided the original author(s) or licensor are credited and that the original publication in this journal is cited, in accordance with accepted academic practice. No use, distribution or reproduction is permitted which does not comply with these terms. 